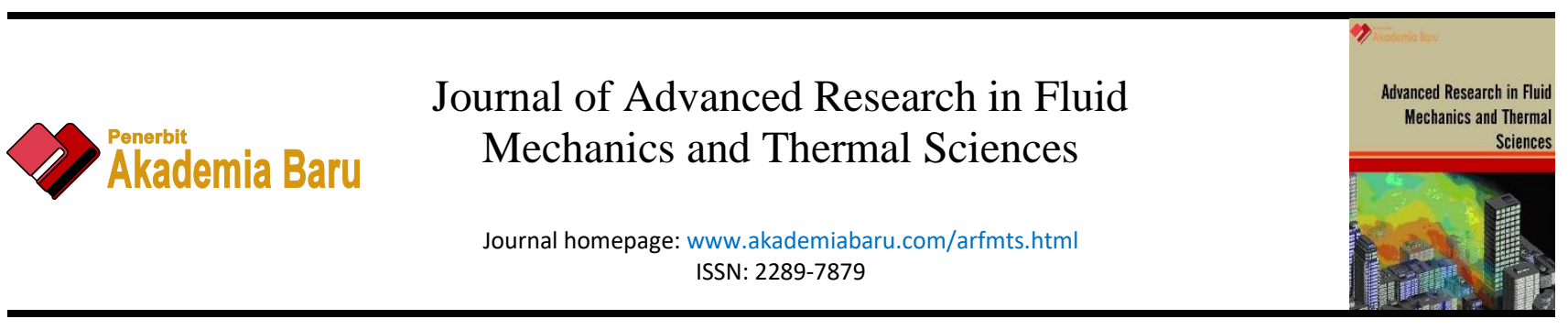

\title{
Experimental and HEC-RAS Modelling of Bridge Pier Scouring
}

\author{
Muqadas Noor ${ }^{1}$, Humaira Arshad², Mujahid Khan ${ }^{3}$, Mahmood Alam Khan ${ }^{4}$, Muhammad Sagheer \\ Aslam ${ }^{5}$, Afnan Ahmad ${ }^{6, *}$ \\ Assistant Engineer, Umar Khayyam Engineering SMC Ltd, Islamabad, Pakistan \\ Lab Engineer, Department of Civil Engineering, Iqra National University, 25124, Peshawar, Pakistan \\ Associate Professor, Department of Civil Engineering, University of Engineering and Technology (UET) Peshawar, 25000, Pakistan \\ Assistant Professor, Department of Agricultural Engineering, University of Engineering and Technology (UET) Peshawar, 25000, Pakistan \\ 5 Assistant Professor, National Institute of Urban Infrastructure Peshawar (NIUIP), University of Engineering and Technology (UET) Peshawar, \\ 25000, Pakistan \\ 6 Research Student, Department of Civil and Environmental Engineering, Universiti Teknologi Petronas (UTP), 32610, Seri Iskandar, Malaysia
}

\section{ARTICLE INFO}

\section{Article history:}

Received 5 April 2020

Received in revised form 2 June 2020

Accepted 4 June 2020

Available online 15 August 2020

\section{Keywords:}

ArcGIS; Bridge pier; Experimental analysis; HEC-RAS; Scouring

\section{ABSTRACT}

A bridge is a vital component of the transportation system and its piers and abutments need to be properly designed for scouring to avoid its damage. The optimal design of the bridge for scouring needs proper scouring analysis using the experimental approach as well as modelling. Without having research-based knowledge of such analysis, it becomes extremely difficult to accurately predict the scouring effects ultimately leading to severe pier damages. This research work is focused on the scouring analysis for a bridge located on Kabul River near Peshawar, Pakistan. The analysis was carried out experimentally, and the results were compared with those obtained from the Hydraulic Engineering Centre, River Analysis Simulation (HEC-RAS) modelling. Although the actual pier shape was circular and for the sake of comparison, an analysis was carried out both for circular and square piers. The data for modelling was collected using Geographic Information System (Arc GIS) and was then used in hydraulic modelling software. In experimental analysis, a total of 10 numbers of experiments were performed using varying discharges and depths of flow. Upstream scour depth results were then compared with hydraulic modelling results. Results showed that square piers result in more scour depth as compared to circular piers. The same trend was observed for scour hole dimensions. A comparison of experimental results with hydraulic software (HEC-RAS) revealed that the later gave slightly larger scour depth values under similar conditions. But this difference was decreasing with the increase in discharge.

Copyright @ 2020 PENERBIT AKADEMIA BARU - All rights reserved

\footnotetext{
* Corresponding author.

E-mail address: afnanahmad905@gmail.com
}

https://doi.org/10.37934/arfmts.74.1.119132 


\section{Introduction}

Bridges are critical structures that require a substantial investment to construct and play a vital role in economic development. The devastation of bridges is inevitable not only in the underdeveloped countries but in the developing countries as well.

Bridge construction is a serious issue which not only requires heavy investment but also needs proper attention to the serious issue of bridge failure that is mainly due to scouring.

Pier scouring is an essential factor in bridge hydraulic design. But the measurement of the bridge's pier scour in the field, especially during flood season, is very difficult. Therefore, Khan et al., [1] experimentally measured various sized and shaped pier for scours in the laboratory. Contour maps were also drawn for the affected area surrounding the piers for checking the extent and damage of possible scouring. It was concluded that the scour depth for the pier with square shape was larger than for circular piers and that scouring increases with increase in size of the pier.

FHWA (2005) The Federal Highway Administration evaluated the risk posed due to scouring for all highway bridges crossing over water and found that scouring can be due to the stream's instability, degradations or/and aggradations, clear water or live bed contraction scour and local scour at piers and abutments. This manual provides "Interim Procedures", guidelines and equations for scour evaluation [2].

Sediment scour around pier and abutment is a serious issue and needs to be addressed. It depends on the shape and size of the pier and many other flow and pier geometry parameters. It is caused by a change in kinetic energy caused by the change of direction in the flow due to manmade construction. It is a very complex phenomenon and its accurate prediction is very difficult. Scour is the arrangement of scour hole around the pier because of the disintegration of soil by the streaming water. The scour opening relies upon the shape and size of the pier, flow depth, the approach of stream and sediment attributes [3].

Scouring is an important phenomenon as it is directly or indirectly contributing to $60 \%$ of the bridge failures. Scour depth is caused by several factors including sediment carrying capacity, flow of river, contraction, variation of the flow path and the pier's geometry. Although scour can be evaluated using theoretical models but due to the uncertainty of numerous parameters, the deterministic approach cannot be adopted [4].

In France, an experimental study was conducted on the collapse of the Wilson Bridge at Tours in 1978 and the results were compared with the numerical 3D finite-element model. The purpose was to assess the vulnerability of a given bridge with one scoured pier and propose a monitoring technique for the evolution of scouring. This investigation has been carried out for the effect of scouring natural frequency of a single pier [5]. Bridge collapse can often be induced by the accumulation of scour during multiple flood events because scour is time-dependent and a single maximum flood event cannot provide complete information about scouring [6]. The response of the structure depends upon sediment composition scour depth [7].

The experimental approach was applied in this study because we can investigate various factors affecting scour in a controlled environment and the same can be used for modeling as well [8]. Besides, Delft3D-FLOW modelling software has been used to investigate the wave flow impact on the bridge piers of Gaadhoo Kao channel [9]. It has been concluded that the hydrodynamic impact can be efficiently reduced by the introduction of bridge piers.

Since the scouring is a natural phenomenon and thus is very unpredictable, therefore a thumb rule for its prediction cannot be ascertained. Therefore, several experimental studies have been carried out to capture each aspect of scour depth. Time and flow dependency of scour depth were observed [10]. The results of the study analyzing sediment impact on pier scour showed that the 
gravel's size has affected circular and square pier scour depths. For both shapes, the scour depth was observed to be increasing with an increase in sediment size [11]. Sediment in suspension also has a great influence on scour depth. It was revealed in a study carried out to see the effect of suspended sediments. A reduction of $50 \%$ in scour depth was observed when suspended sediment was ignored [12]. To understand the phenomenon of scouring, the experimental approach is normally used because its investigation in the field is very difficult and challenging. Due to the recent flood of 2010, the researchers diverted their focus towards bridges' pier and abutment scouring.

Clearwater scours for cylindrical, square and diamond were investigated both experimentally and numerically. This study is carried out to check the predictive capability of the URANS morph dynamic model for the diamond pier for which sediment transport is driven by shear layer from pier sharp edges. It was concluded that this model cannot resolve horseshoe vertex, significantly under predicts both scour depth and its rate at nose pier [13]. A study on the time development of local scour around a complex pier was conducted using a small-scale model in a laboratory. A total of 15 numbers of experiments were conducted. Based on these experimental results, empirical formulas for scouring cavity time development and relation between scour depths and scour cavity volumes were obtained [14]. Melville et al., [15] studied pier scour depth and relevant variables including flow intensity, flow shallowness, Euler and Reynolds number, sediment coarseness. Much emphasis was on the basic mechanism of local scour.

Many researchers predict scour depth using Artificial Intelligence modeling like Muzzammil et al., [16]. They used Gene Expression Programming (GEP) using laboratory data to predict pier scour depth. Mathematical models (1D and 2D) were applied by Moussa [17]. Results showed that the 2D model of the non-uniform cross-section gives the more accurate result as compared to the 1D model especially for sharp-nosed piers normal to the flow. Time to equilibrium is among the most important variables that are affecting pier scour. Since the scour varies with time of flow, therefore it is important to study the temporal variation. For this purpose, a semi-empirical model was developed by Yanmaz and Selamoğlu [18] to estimate the time to equilibrium scour depth. Results showed that this empirical equation was very effective.

In summary, the researchers have calculated pier scour using different numerical and hydraulic software as well as experimental analysis due to its importance in bridge design, but a very common hydraulic software i.e. HEC-RAS is rarely used for scouring and its results are not validated through experimental analysis. Therefore, in this research study, an attempt is being made to estimate pier scour depth in the laboratory and compare the results with the one obtained from HEC-RAS modelling for a bridge located on Kabul River near Peshawar.

\section{Materials and Methods}

This research is carried out in two steps. In first step the scour depth is measured experimentally while in the second step, the same is calculated using HEC-RAS. Experimental as well as HEC-RAS modelling is discussed in detail below.

\subsection{Experimental Setup}

Firstly, the pier scours depth was measured experimentally in the Civil Engineering Department (hydraulic laboratory), UET, Peshawar. Before performing the experiments, similitude analysis was carried out for small scale modeling using geometric similarity. After selecting the appropriate size of the pier and other flow parameters, sieve analysis was carried out on sediment samples collected from the site. Then the experimental setup was prepared as discussed below. 


\subsubsection{Open channel flume}

The rectangular flume used for experiments is $15.8 \mathrm{~m}$ long, $0.3 \mathrm{~m}$ wide and $0.37 \mathrm{~m}$ deep as shown in Figure 1 below. Centrifugal pump is used to supply water to the channel from the underground tank and is re-circulated. A point gauge is installed for the measurement of flow depth and scour depth. Rectangular notch installed in the channel is used to measure the discharge. Pier models of circular as well as a square shape were used for experiments.

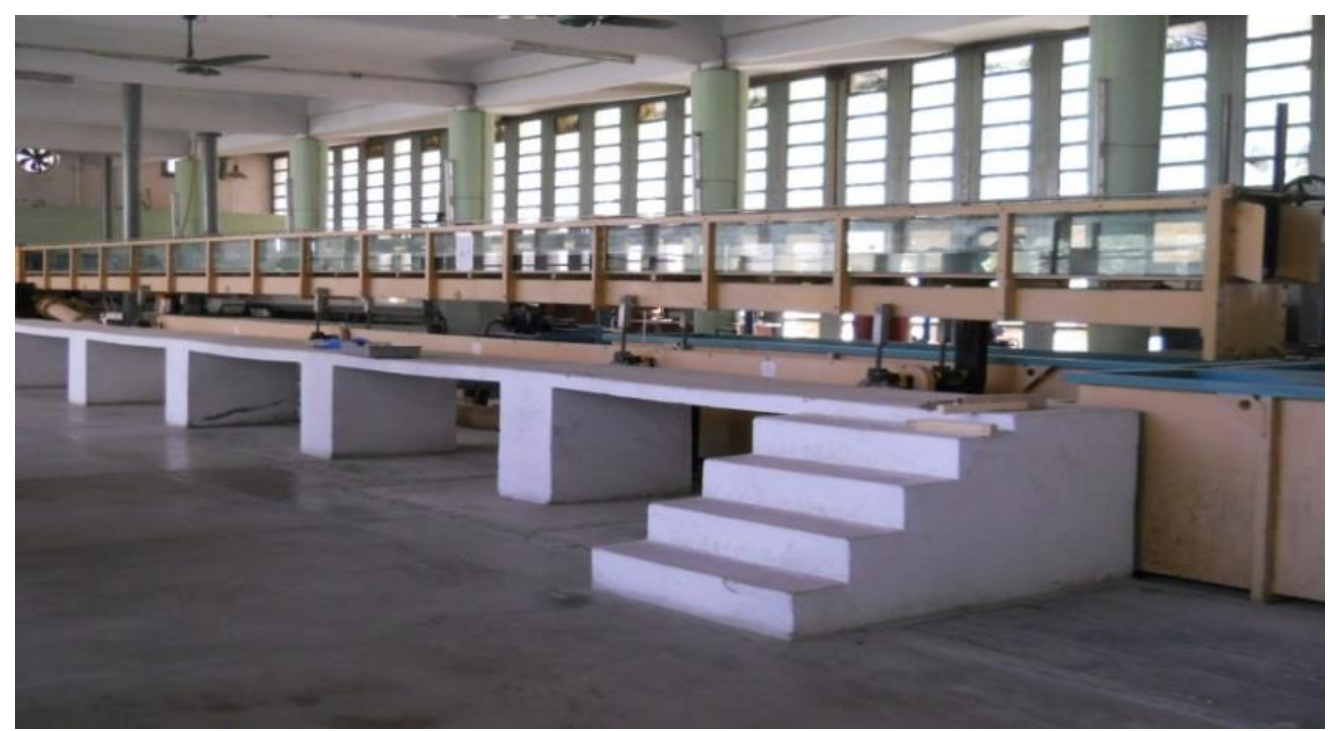

Fig. 1. Rectangular Flume in Hydraulic Laboratory

\subsubsection{Channel bed preparation}

To install the pier, a bed was prepared in the form of a test section which was made by installing glass at the start and end of it and filling the space between them with sediments obtained from sieve analysis having a $d_{50}$ of $0.5 \mathrm{~mm}$. The test section was $0.1 \mathrm{~m}$ high, $3.0 \mathrm{~m}$ long and $0.3 \mathrm{~m}$ wide. Pier model of $3 \mathrm{~cm}$ was installed at the centre after filling the test section with sediment and levelling it. The test section with filled sediment is shown in Figure 2 for the circular pier and in Figure 3 for the square pier.

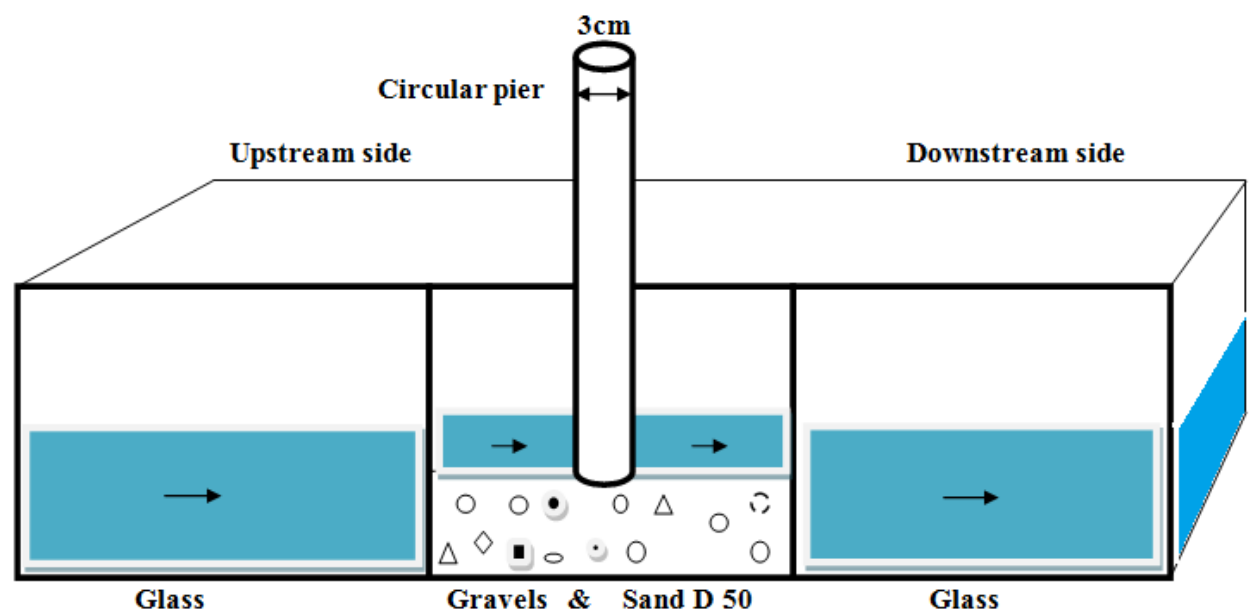

Fig. 2. Circular pier installed in the test section 


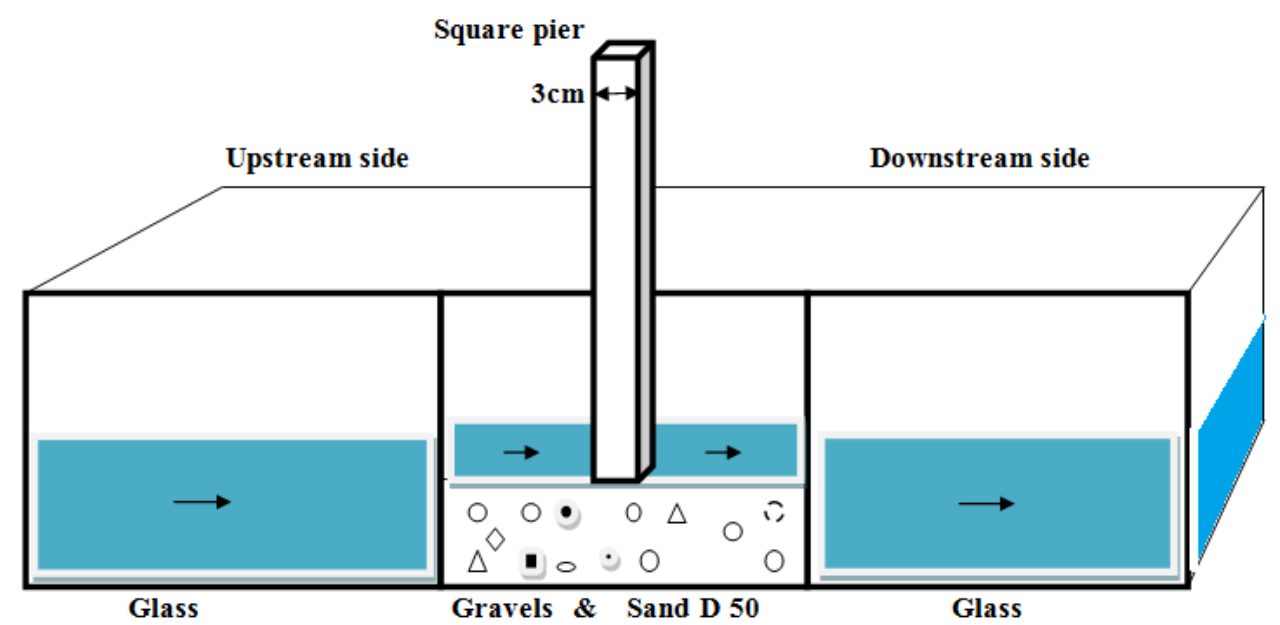

Fig. 3. Square pier installed in the test section

\subsubsection{Experimental procedure}

Channel bed smoothens after pier installation and pier scour depth measurements were taken at the required points. These points were widespread on upstream $(u / s)$, downstream $(d / s)$, and both sides of the pier. Water then passes through the pier model in the channel. The discharge was measured using a rectangular notch and verified by using the volumetric method. Each experiment was run for 45 minutes. The scour depth, as well as width and length of the scour hole, were measured at all pre-selected points after draining out the water. The same procedure is repeated for all other experiments. The results are tabulated and discussed in the section to follow.

\subsection{HEC-RAS Analysis}

HEC-RAS (2001) was also used to evaluate scour around the piers of Pashtun Garhi Bridge in Nowshera. It is a one-dimensional model simulating sediment transport for moveable boundary conditions both for steady and unsteady flow conditions. The readers are referred to as HEC-RAS manual 5.0.3 for further details. HEC-RAS required geometry and flow data of the river. Geometry data contain several $x$-sections upstream and downstream of the bridge, the distance between them and the roughness coefficient of the river and flood plain while flow data contain the discharge for different return periods. Several $x$-sections depend on river variability. The $x$-sections in this study were generated using Arc GIS software. These $x$-sections, after putting in HEC-RAS, are shown in Figure 4 below. 


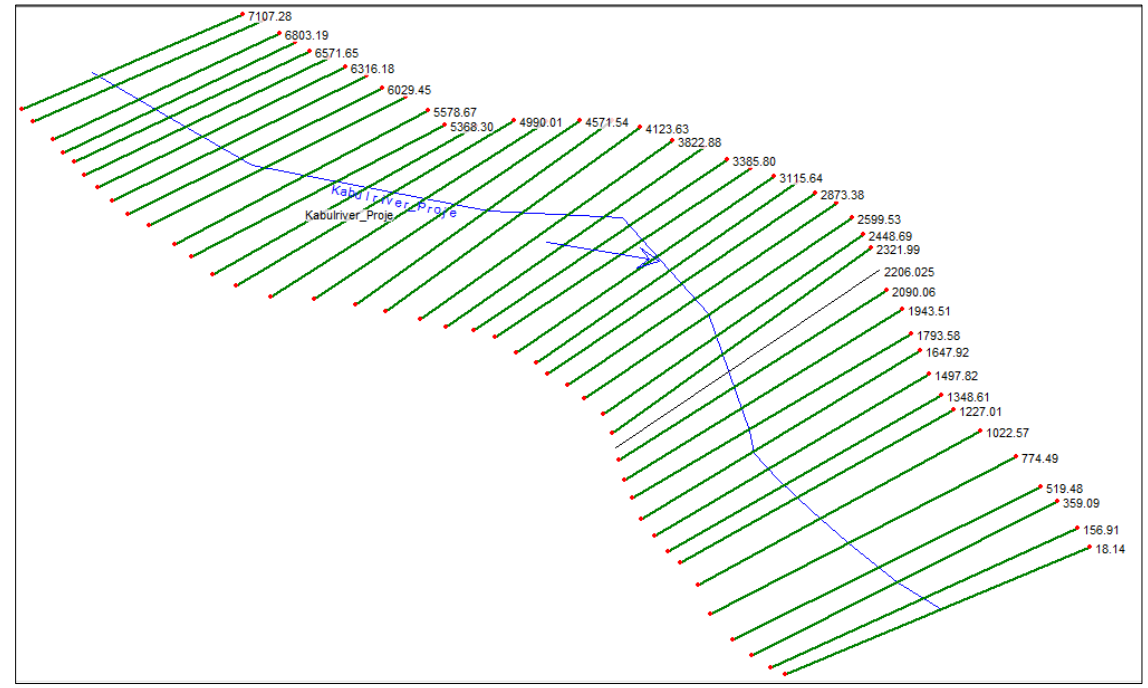

Fig. 4. River and its $x$-sections plotted in HEC-RAS along the river reach

\subsubsection{HEC-RAS Input Data}

HEC-RAS needs flow data, manning roughness for the channel as well as flood plain and river geometry. Figure 5 shows a typical cross-section which required the distance measured from one side of the river and elevation at that point. Besides this, the roughness coefficient, the distance between Left Over the Bank (LOB), Right Over the Bank (ROB) and centre of the two-consecutive $x$ sections were entered.

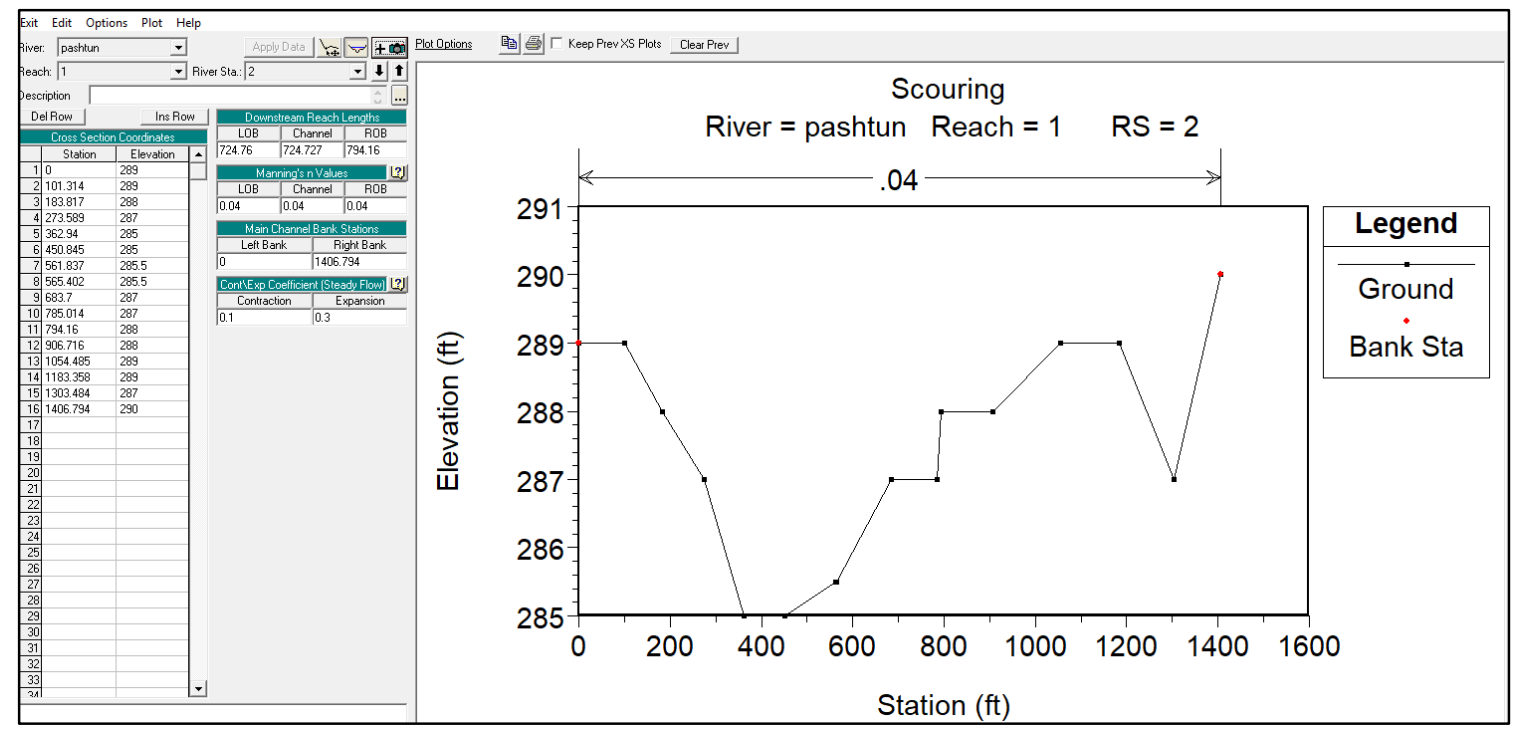

Fig. 5. Typical Cross-Section data inserted in HEC-RAS

\subsubsection{Pashtun Garhi bridge input data into HEC-RAS}

The bridge under study is modelled in HEC RAS. The total length of bridge is 4.2-kilometre containing thirteen circular piers each of $0.5 \mathrm{~m}$ diameter and 14 spans. Each span is $30 \mathrm{~m}$ long between the pier centres. It has two abutments with stone pitching. Weir coefficient is taken as 1.4 and submergence 0.98. The width of the bridge is $8 \mathrm{~m}$. The lower chord of bridge deck is at $294.5 \mathrm{~m}$ elevation while the high chord is at $297 \mathrm{~m}$. All these dimensions are shown in Figure 6 below. For bridge scouring along with the geometric information as mentioned above, some other factors were 
entered into HEC RAS model. These factors include $K_{1}$ (shape factor), correction factor for angle of attack $K_{2}$, bed condition correction factor $k_{3}$. Values of $K_{1}, K_{2}$, and $K_{3}$ were taken as 1.0, 3.5 and 1.1 for circular shape, zero angle of attack and clear water condition respectively. $K_{4}$ was also taken as 1.0. Median size sediment $D_{50}$ used was $0.55 \mathrm{~mm}$.

\subsubsection{HEC-RAS application procedure}

The river $x$-sections for HEC-RAS were obtained from the DEM model using QGIS. The other information about bridge geometry and flow required for HEC-RAS were obtained in a site visit to the bridge. After starting a new project in HEC-RAS, the data collected from the site visit and QGIS was entered. It includes geometry data as well as flow data. A geometric shapefile was created for the roughness coefficient of 0.04 was used for the left of channel, right of channel and main channel sections for all the sections of the reach. After entering all the river data, the bridge is inserted into HEC-RAS. The bridge edit button enables, entered data of bridge including bridge length, width deck level, also upstream and downstream sections were defined as shown in Figure 6 below. Reach boundary conditions were defined as normal flow in which the slope of the river was required. The slope calculated from the selected $x$-sections was found to be 0.001 . After the hydraulic analysis is done, some data required for contraction scour, pier scour and abutment scour are automatically taken by HEC-RAS except some factors like $D_{50}, K_{1}$, and $K_{2}$. The value of $D_{50}$ for Kabul River was used while other factors were obtained from HEC-18. After putting all the data, HEC-RAS is run and depth of contraction scour, pier scour and abutment scour were obtained.

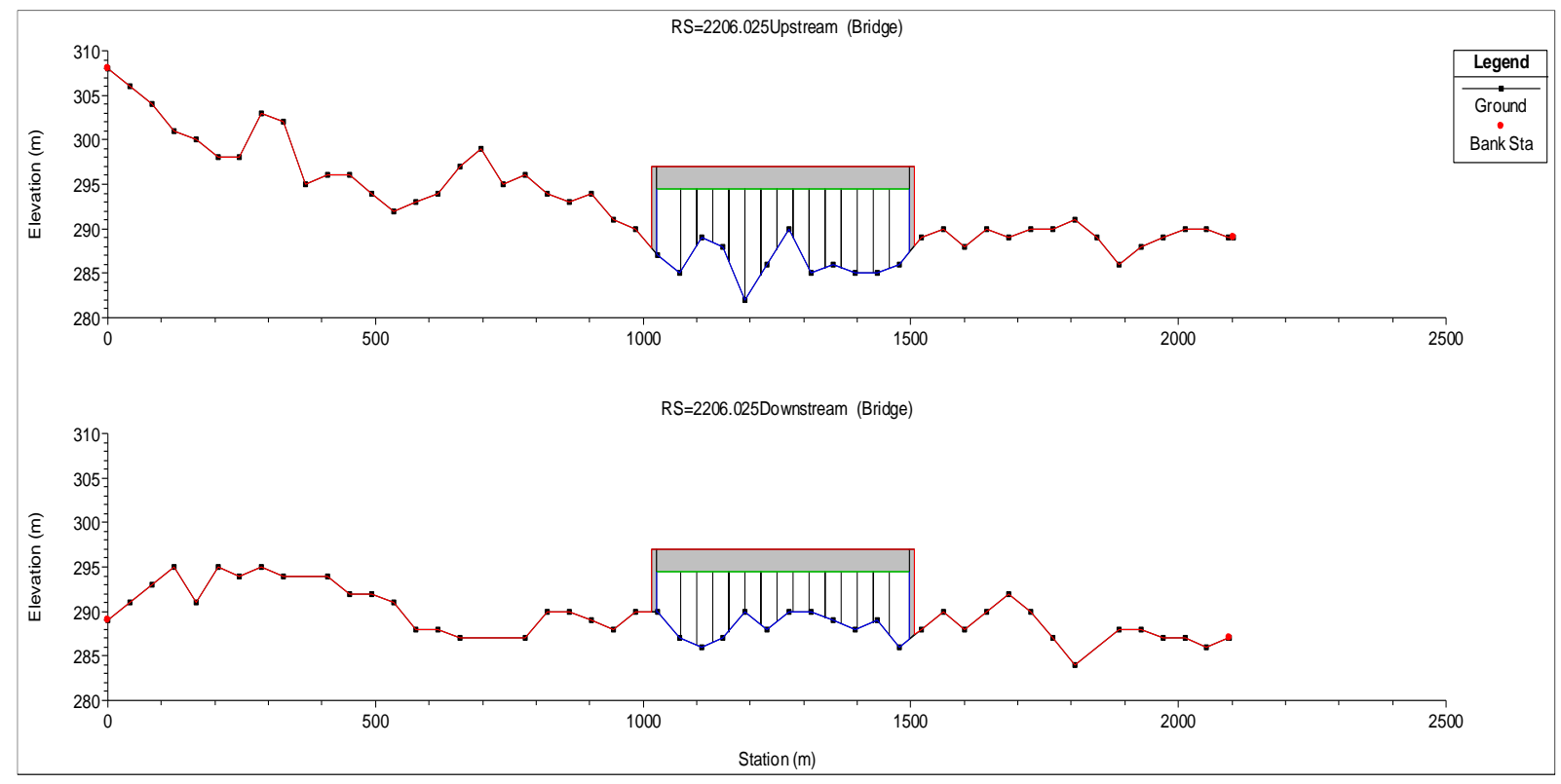

Fig. 6. Bridge deck along with piers modelled in HEC-RAS

\section{Results and Discussion}

This section demonstrates the experimental as well as HEC-RAS modelling in detail.

\subsection{Experimental Results}

Experimental results are summarized in tabular form (Table 1) and are presented in figures below including scour depth and scour hole dimensions. The figures revealed variation in these quantities 
with variation in discharge and the pier's shape and size. Since maximum scours occurred at the $u / s$ side, that value will be used. During the experiment, it was observed that initially there was rapid scouring and was decreased as time elapsed. The duration of the experiment was 45 minutes. Five experiments were carried out for circular and the same number of experiments were conducted for the square model with the later giving higher results.

Table 1

Result obtained from experimental analysis for pier scouring

\begin{tabular}{llllllllll}
\hline Pier Shape & $\begin{array}{l}\mathrm{y} \\
\text { (cm) }\end{array}$ & $\begin{array}{l}\text { Discharge } \\
\text { (liter/sec) }\end{array}$ & $\begin{array}{l}\text { Time } \\
\text { (minute) }\end{array}$ & $\begin{array}{l}\text { Scour depth } \\
\text { Up- } \\
\text { stream } \\
\text { (cm) }\end{array}$ & $\begin{array}{l}\text { Down- } \\
\text { stream } \\
(\mathrm{cm})\end{array}$ & $\begin{array}{l}\text { Left } \\
\text { (cm) }\end{array}$ & $\begin{array}{l}\text { Right } \\
(\mathrm{cm})\end{array}$ & $\begin{array}{l}\text { Scour } \\
\text { Length } \\
(\mathrm{cm})\end{array}$ & $\begin{array}{l}\text { Scour } \\
\text { Width } \\
(\mathrm{cm})\end{array}$ \\
\hline Circular Pier & 6.2 & 4.9 & 60 & 6.1 & 6.5 & 5.7 & 6.6 & 22.7 & 22.5 \\
Circular Pier & 5.9 & 4.5 & 60 & 4.7 & 2.5 & 3 & 3.4 & 18.3 & 17.7 \\
Circular Pier & 5.9 & 4.5 & 45 & 4.4 & 2.4 & 2.8 & 2.3 & 18 & 19.4 \\
Circular Pier & 3.5 & 3.6 & 60 & 3.5 & 3.5 & 4.3 & 4.3 & 17.3 & 18 \\
Circular Pier & 3.5 & 3.6 & 45 & 3.2 & 3.5 & 3.5 & 4.3 & 16.9 & 17.6 \\
Square Pier & 5.9 & 4.9 & 60 & 7 & 5.7 & 4.8 & 5 & 27.3 & 24.2 \\
Square Pier & 5.9 & 4.5 & 60 & 6.2 & 4 & 5.2 & 4.9 & 26.2 & 23.1 \\
Square Pier & 5.9 & 4.5 & 45 & 5.6 & 5.5 & 5.1 & 7 & 24.4 & 21.6 \\
Square Pier & 3.5 & 3.6 & 60 & 5.4 & 2.9 & 4.4 & 4.6 & 22.8 & 20.8 \\
Square pier & 3.5 & 3.6 & 45 & 4.7 & 3.9 & 5.7 & 5.6 & 18.8 & 19.9 \\
\hline
\end{tabular}

\subsubsection{Plots for scour depth at circular pier}

The results obtained were plotted against the discharge of its relationship with scouring depth. Circular and square pier comparison is shown in Figure 7 below. Similarly, scour hole dimensions were also drawn for both pier model and different discharge and its comparison is shown in Figure 8 for the length of the scour hole and Figure 9 for the width of the scour hole.

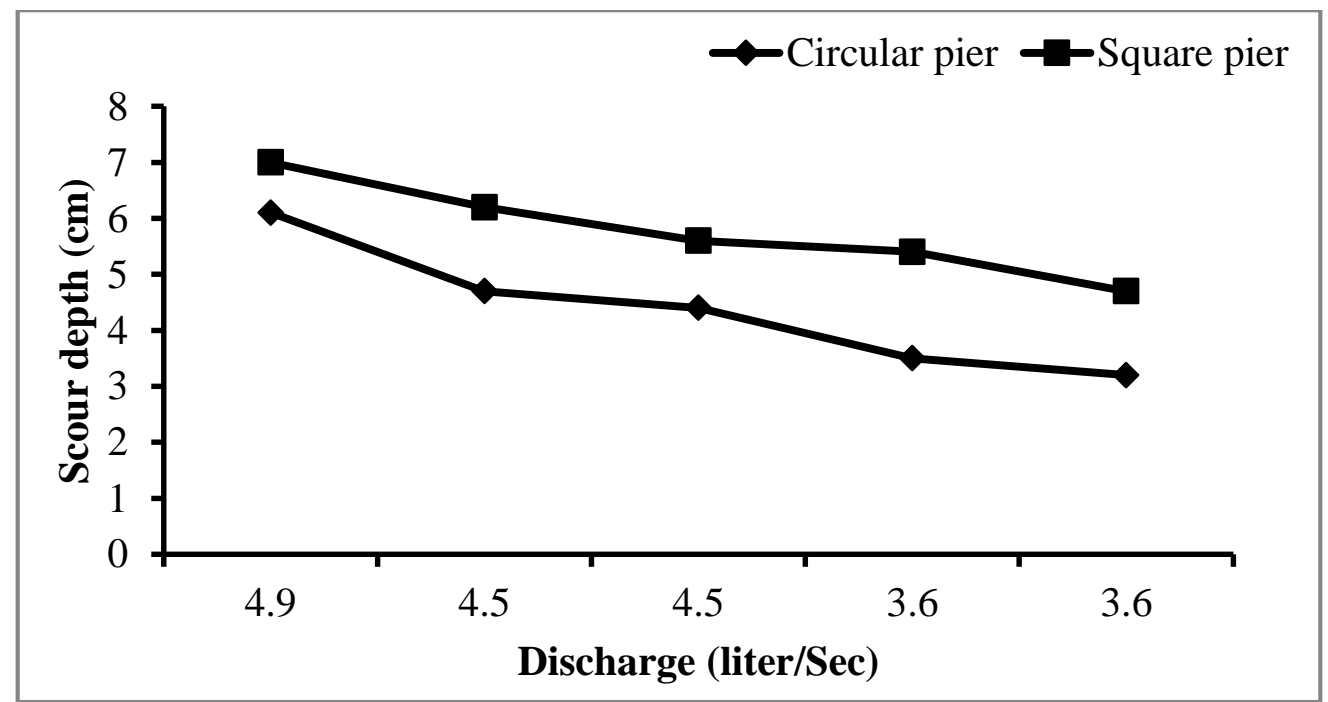

Fig. 7. Comparative graph of scour depth of square and circular piers along with variant discharge

Figure 7 reveals that the square pier resulted in higher scour depth as compared to a circular pier. The figure also shows a direct relation between scour depth and discharge. The same trend was shown by Khan et al., [1]. 


\subsubsection{Comparison for scour hole length for both types of model}

Figure 8 shows that the length of the scours hole increases with an increase in discharge for both types of pier models.

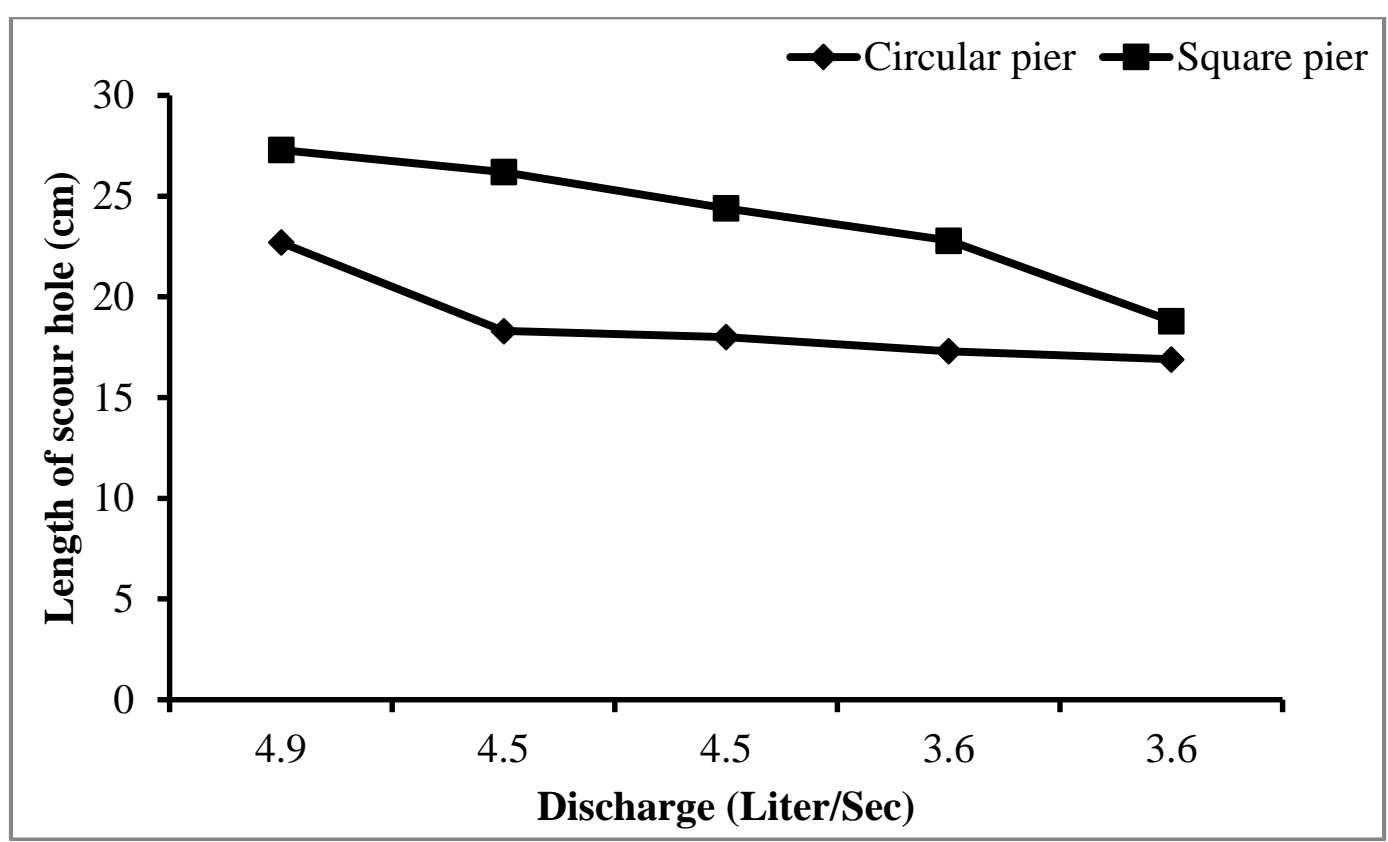

Fig. 8. Comparative graph of length of scour hole of circular and square piers along with variant discharge

\subsubsection{Comparison of scour hole width for both type of analysis}

Figure 9 shows the direct relationship between the length of the scour hole and discharge for both types of pier models.

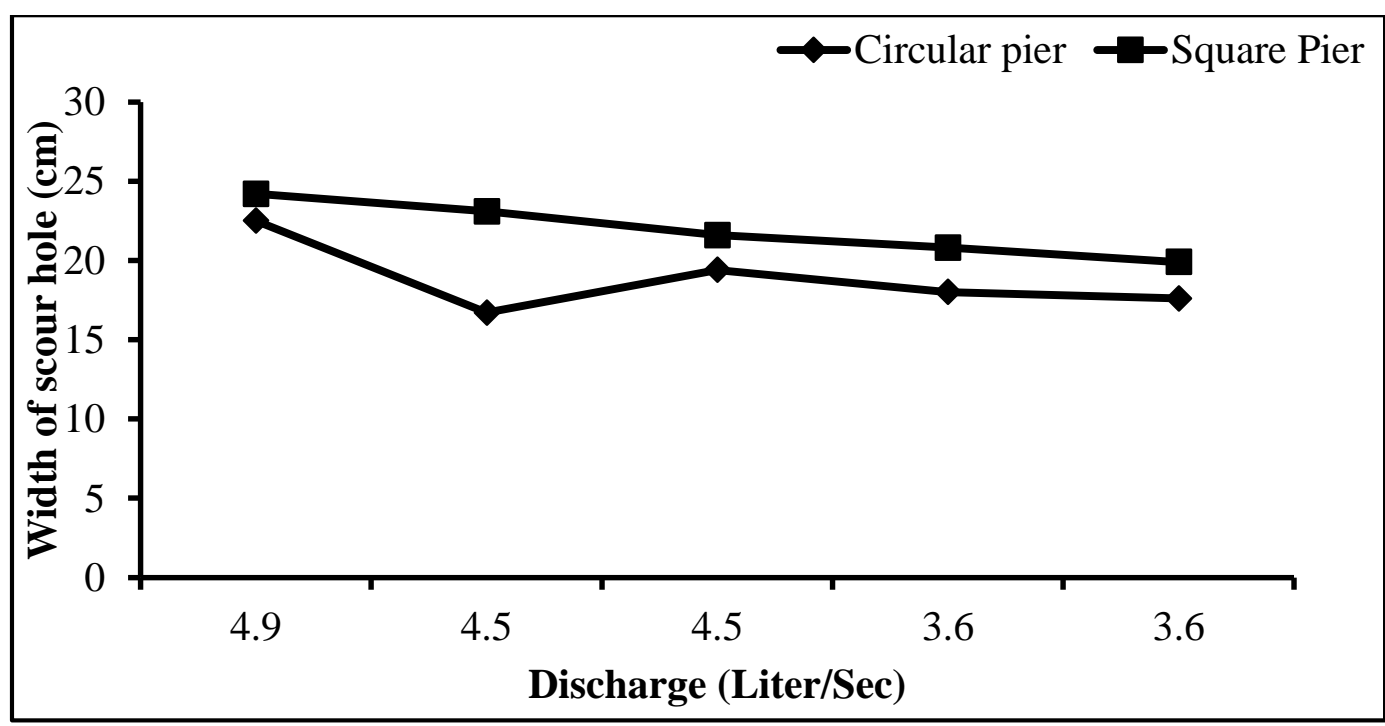

Fig. 9. Comparative graph of a width of the scour hole of circular and square piers along with variant discharge 


\subsection{HECRAS Results}

\subsubsection{Water level in bridge}

As discussed in the HEC-RAS application procedure above, all the required data for $\mathrm{x}$-sections as well as bridge and pier geometry were entered into HEC-RAS. After performing the simulation for a given flow and boundary conditions, the results were obtained. Since we were interested in Bridge hydraulics only, therefore Figure 10 below shows the water level in the bridge for all the discharge conditions.

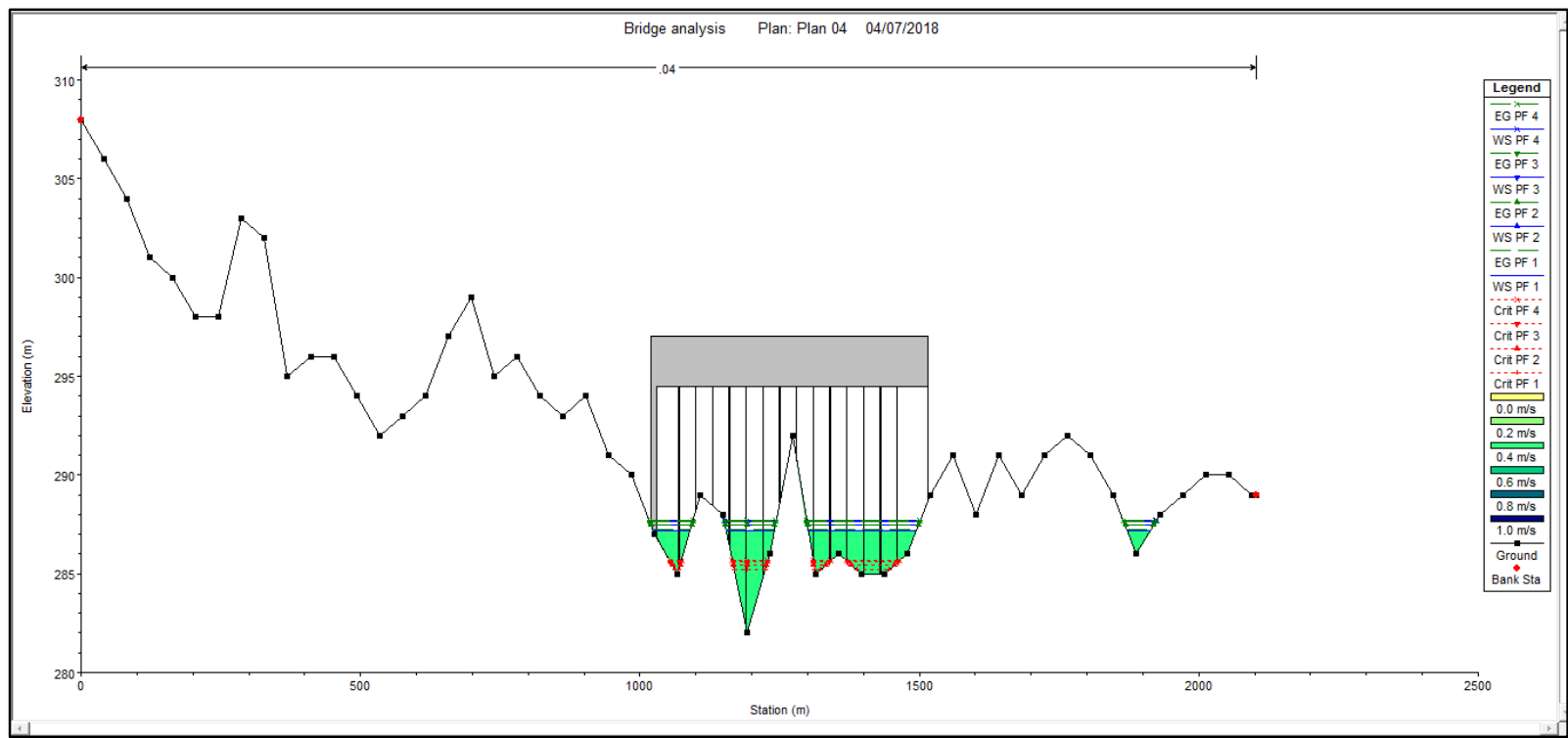

Fig. 10. Water level in the bridge along with the varying discharges

Figure 10 shows that even for the maximum discharge of 10,000 cumecs, the high flood level is well below the lower deck level and is safe. But here we are interested in bridge pier to scour. The scour depth at the pier will be the sum of contraction scour as well as local scour at piers.

\subsubsection{Ccouring at bridge using HEC-RAS}

The data to calculate contraction scour depth and local scour depth at piers, and an abutment is entered. In HEC-RAS, pier scour depth is taken as the sum of local scour and contraction scour depth. The contraction scour was calculated using clear water or live bed contraction scour equation [8]. Similarly, local scour depth was calculated using Colorado State University (CSU) equation [19]. The CSU equation required only pier nose shape $\left(K_{1}\right)$, the angle of attack for flow $\left(K_{2}\right)$ the bed condition $\left(K_{3}\right), D_{50}$ and $D_{95}$ of sediment size of bed material. After doing hydraulic design function analysis in HEC-RAS, the scour depth is calculated as shown in Figure 11, while its comparison is shown in Table 2 below. 


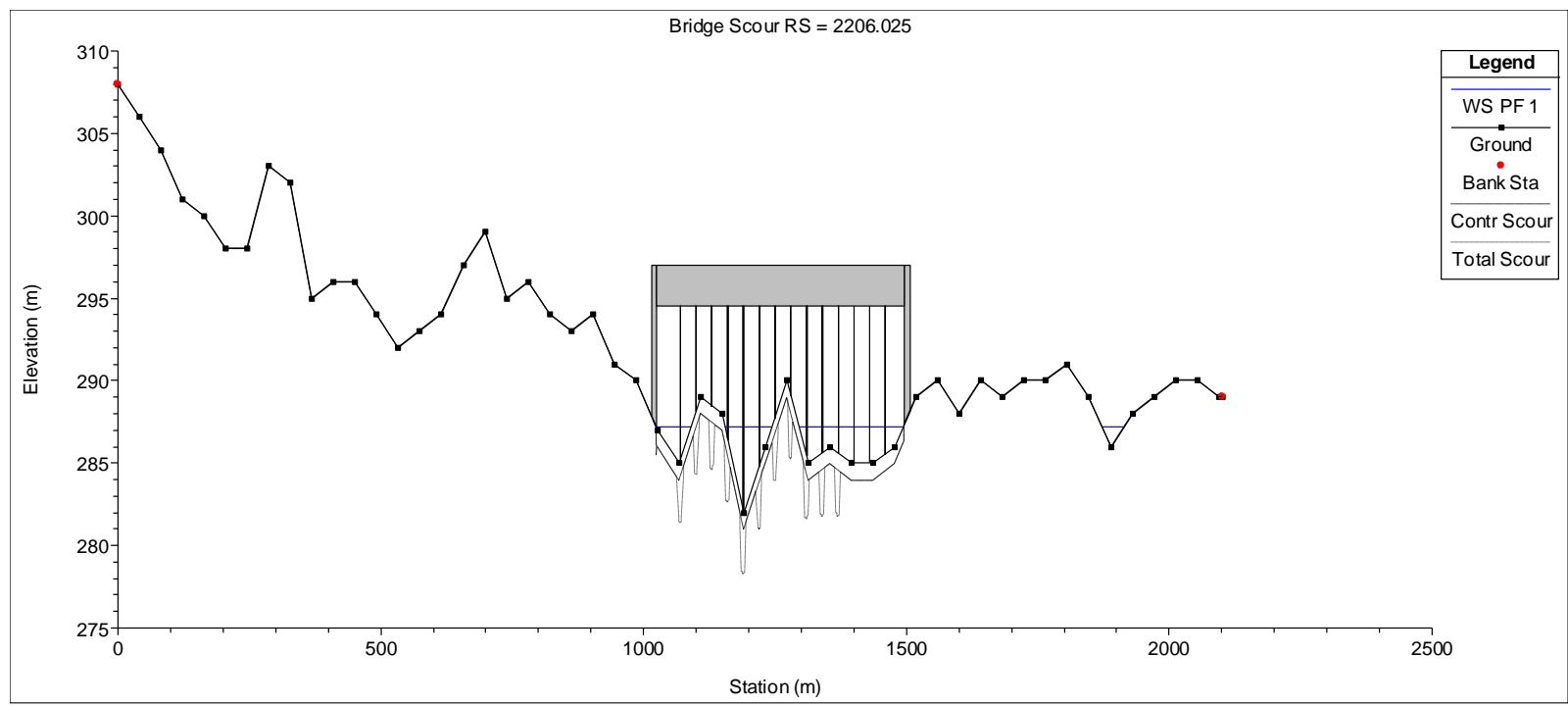

Fig. 11. Scouring computation across piers along discharge variation involving variant factors

3.2.3 Comparison of experimentally measured pier scour depth and calculated scour depth from HECRAS

Results in Tables 2 above show comparison of experimental pier and HEC-RAS calculated pier scour depth. Results show that the HEC-RAS results are closely related to the measured scour depth. It also shows that HEC-RAS calculated pier scours depth for circular pier are very close to experimental results as compared to the square pier scour depth. It also shows that as the discharge goes on decreasing, the results become much closer. To further explore the comparison of HEC-RAS and experimental results, data obtained is plotted in Figure 12 to Figure 14 below.

\section{Table 2}

Comparison of HEC-RAS and experimental results for different pier shapes scour depth

\begin{tabular}{|c|c|c|c|c|c|c|}
\hline \multirow[t]{2}{*}{ Experiment } & \multirow[t]{2}{*}{ Pier Shape } & \multirow{2}{*}{$\begin{array}{l}\text { Time } \\
\text { (minute) }\end{array}$} & \multirow{2}{*}{$\begin{array}{l}\text { Discharge } \\
\text { Experimental } \\
\text { (Liter/sec) }\end{array}$} & \multicolumn{3}{|c|}{ Scouring $(m)$} \\
\hline & & & & $\begin{array}{l}\text { HEC-RAS } \\
\left(\mathrm{m}^{3} / \mathrm{sec}\right)\end{array}$ & $\begin{array}{l}\text { Experimental } \\
(\mathrm{m})\end{array}$ & $\begin{array}{l}\text { HEC-RAS } \\
(\mathrm{m})\end{array}$ \\
\hline 1 & Circular & 60 & 4.9 & 498 & 6.1 & 4.60 \\
\hline 2 & & 60 & 4.5 & 458 & 4.7 & 4.46 \\
\hline 3 & & 45 & 4.5 & 458 & 4.4 & 4.46 \\
\hline 4 & & 60 & 3.6 & 368 & 3.5 & 4.22 \\
\hline 5 & & 45 & 3.6 & 368 & 3.2 & 4.22 \\
\hline 6 & Square & 60 & 4.9 & 498 & 7 & 4.64 \\
\hline 7 & & 60 & 4.5 & 458 & 6.2 & 4.54 \\
\hline 8 & & 45 & 4.5 & 458 & 5.6 & 4.54 \\
\hline 9 & & 60 & 3.6 & 368 & 5.4 & 4.3 \\
\hline 10 & & 45 & 3.6 & 368 & 4.7 & 4.3 \\
\hline
\end{tabular}

\subsubsection{Comparison plots for scour depth estimated using HEC-RAS}

Data shown in Table 2 above is plotted in Figure 12 to Figure 14 below. Figure 12 shows a comparison of HEC-RAS results for both pier models. It shows almost the same trend as shown by experimental results. 


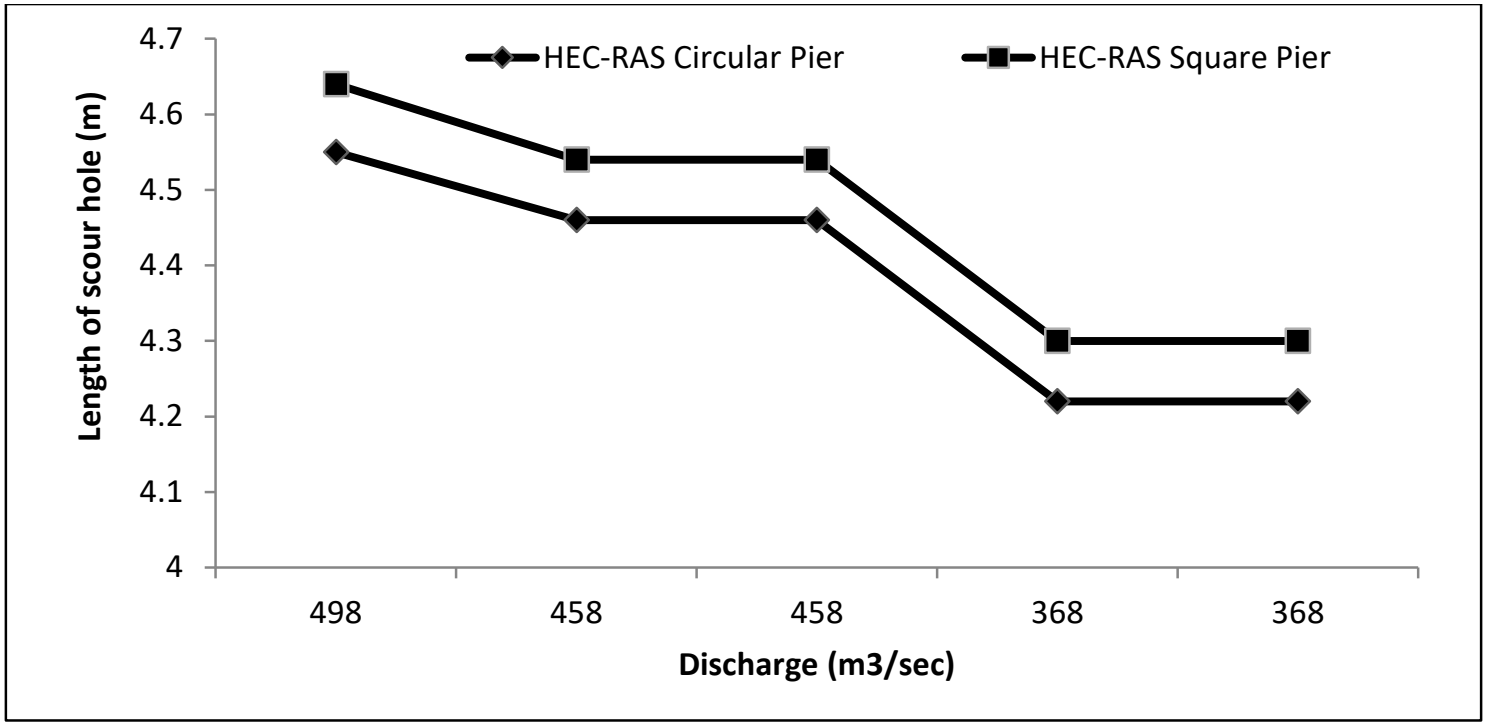

Fig. 12. HEC-RAS scour depth comparison for square and circular piers along with variant discharge

Figure 13 shows a scour depth comparison for the square pier calculated using HEC-RAS and measured using experimental analysis. The results showed that initially for higher discharge the gap between the HEC-RAS and experimental scour depth is greater but as the discharge goes on decreasing, the gap between the two results also reduces. But it was shown that the gap between the two results for the square pier is greater as compared to a circular pier.

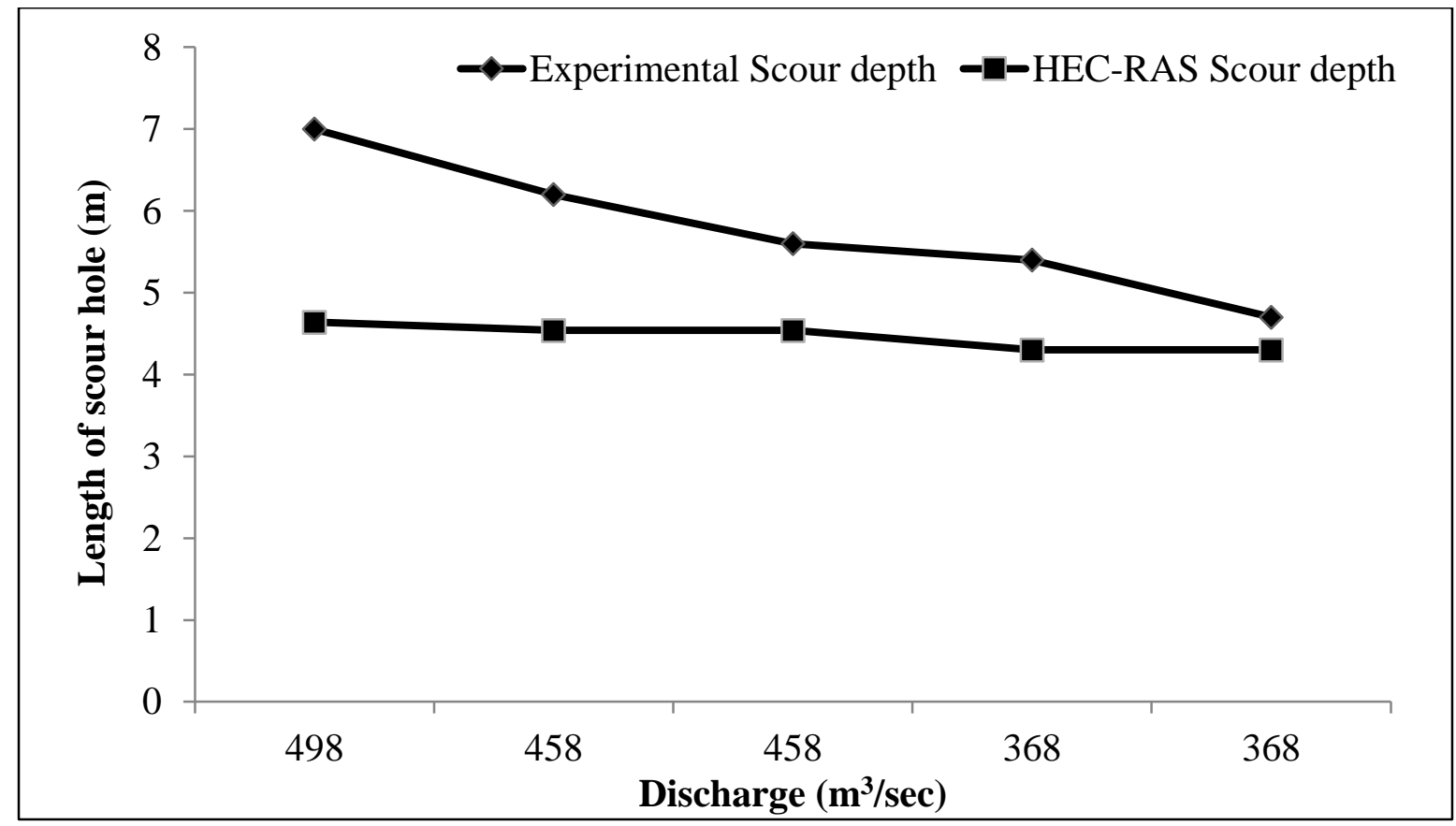

Fig. 13. Comparison of Experimental \& HEC-RAS square pier

Figure 14 shows the comparison of HEC-RAS and experimental scour depth for the circular pier. The results show that the results are much closer to one another. 


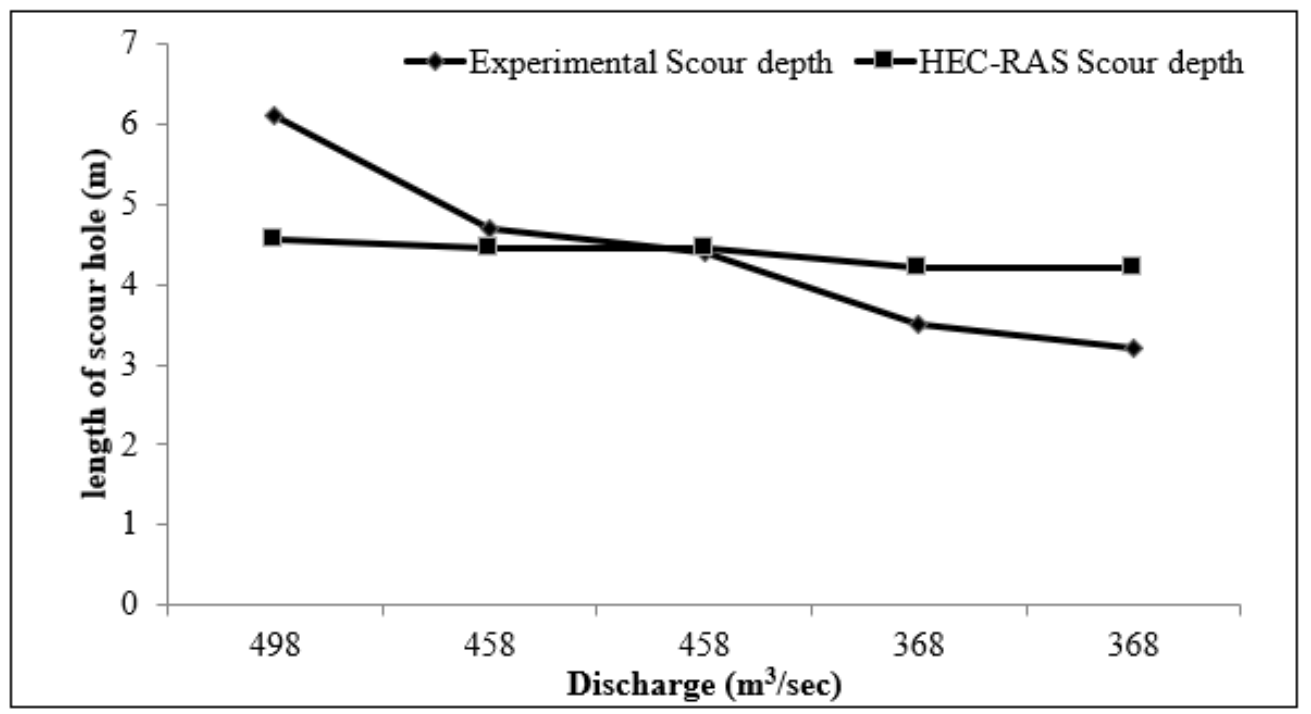

Fig. 14. Comparison of Experimental \& HEC-RAS square pier

\section{Conclusions}

The following conclusions were drawn from the results.

i. Experimentally, scour depth and scour hole dimensions for the square pier were greater than the circular pier model. The same results were also shown by Khan et al., [1].

ii. HEC-RAS results show close relation with experimental results, especially for low discharges.

iii. HEC-RAS and experimental results were closely related to the circular pier as compared to the square pier.

\section{References}

[1] Khan, Mujahid, Muhammad Tufail, Muhammad Ajmal, Zia UI Haq, and Tae-Woong Kim. "Experimental analysis of the scour pattern modeling of scour depth around bridge piers." Arabian Journal for Science and Engineering 42, no. 9 (2017): 4111-4130.

https://doi.org/10.1007/s13369-017-2599-7

[2] Richardson, Everett V., Stanley R. Davis, and Peter F. Lagasse. "Comprehensive Scour Analysis at Highway Bridges HEC-IS." In Proceedings 5th International Conference on Scour and Erosion (ICSE-5), November 7-10, 2010, San Francisco, USA, pp. 1092-1101. 2010.

[3] Kumar, P. Deepak, and P. R. Maiti. "Three-Dimensional CFD Modeling of Flow Field and Scouring around Bridge Piers." International Journal of Civil and Environmental Engineering 10, no. 4 (2016): 1-8.

[4] Malerba, Pier Giorgio, Elsa Garavaglia, and Luca Sgambi. "Fuzzy-Monte Carlo simulation for the safety assessment of bridge piers in presence of scouring." in The 2011 World Congress on Advances in Structural Engineering and Mechanics (ASEM'11+), September, 2011, Seoul, Korea, pp. 18-22. 2011.

[5] Boujia, N., F. Schmidt, D. Siegert, D. Pham Van Bang, and C. Chevalier. "Modelling of a bridge pier subjected to scour." Procedia Engineering 199 (2017): 2925-2930.

https://doi.org/10.1016/i.proeng.2017.09.343

[6] Tubaldi, Enrico, Lorenzo Macorini, Bassam A. Izzuddin, Costantino Manes, and Francesco Laio. "A framework for probabilistic assessment of clear-water scour around bridge piers." Structural Safety 69 (2017): 11-22.

https://doi.org/10.1016/i.strusafe.2017.07.001

[7] Klinga, John V., and Alice Alipour. "Assessment of structural integrity of bridges under extreme scour conditions." Engineering Structures 82 (2015): 55-71. https://doi.org/10.1016/i.engstruct.2014.07.021

[8] Laursen, Emmett M., and Arthur Toch. Scour Around Bridge Piers and Abutments. Vol. 4. Ames, IA: lowa Highway Research Board, 1956.

[9] Shiraz, Hassan, and Mohamad Hidayat Jamal. "Hydrodynamic modelling of a sea-crossing bridge in Maldives." Journal of Advanced Research Design 56, no. 1 (2019): 10-25. 
[10] Elsebaie, Ibrahim H. "An experimental study of local scour around circular bridge pier in sand soil." International Journal of Civil \& Environmental Engineering IJCEE-IJENS 13, no. 01 (2013): 23-28.

[11] Raikar, R. V., and S. Dey. "Scour of gravel beds at bridge piers and abutments." In Proceedings of the Institution of Civil Engineers-Water Management, vol. 158, no. 4, pp. 157-162. Thomas Telford Ltd, 2005. https://doi.org/10.1680/wama.2005.158.4.157

[12] Baykal, Cüneyt, B. Mutlu Sumer, David R. Fuhrman, Niels Gjøl Jacobsen, and Jørgen Fredsøe. "Numerical investigation of flow and scour around a vertical circular cylinder." Philosophical Transactions of the Royal Society A: Mathematical, Physical and Engineering Sciences 373, no. 2033 (2015): 20140104. https://doi.org/10.1098/rsta.2014.0104

[13] Khosronejad, Ali, Seokkoo Kang, and Fotis Sotiropoulos. "Experimental and computational investigation of local scour around bridge piers." Advances in Water Resources 37 (2012): 73-85. https://doi.org/10.1016/i.advwatres.2011.09.013

[14] Ramos, Pedro Xavier, Ana Margarida Bento, Rodrigo Maia, and João Pedro Pêgo. "Characterization of the Scour Cavity Evolution around a Complex Bridge Pier." Journal of Applied Water Engineering and Research 4, no. 2 (2015): 128-137. https://doi.org/10.1080/23249676.2015.1090353

[15] Melville, Bruce W. "The physics of local scour at bridge piers." In Proceedings 4th International Conference on Scour and Erosion (ICSE-4), November 5-7, 2008, Tokyo, Japan, pp. 28-40. 2008.

[16] Muzzammil, Mohammad, Javed Alama, and Mohammad Danish. "Scour prediction at bridge piers in cohesive bed using gene expression programming." Aquatic Procedia 4 (2015): 789-796. https://doi.org/10.1016/i.aqpro.2015.02.098

[17] Moussa, Ahmed Moustafa Ahmed. "Evaluation of local scour around bridge piers for various geometrical shapes using mathematical models." Ain Shams Engineering Journal 9, no. 4 (2018): 2571-2580. https://doi.org/10.1016/i.asej.2017.08.003

[18] Yanmaz, A. M., and M. Selamoğlu. "A Case Study on Bridge-Scour Risk Assessment." In 9th International Congress on Advances in Civil Engineering, September 27-30, 2010, Trabzon, Turkey. 2010.

[19] Richardson, E. V., and J. R. Richardson. Bridge-Scour Data Management System User's Manual. Colorado State University, 1990. 